\title{
RESPONSE OF TUBER YIELD QUANTITY AND QUALITY OF POTATO PLANTS AND ITS ECONOMIC CONSIDERATION TO CERTAIN BIOREGULATORS OR EFFECTIVE MICROORGANISMS UNDER POTASSIUM FERTILIZATION
}

Arafa, A. A. ; S. F. M. Hussien and Hager S. G. Mohamed

Agric. Bot. Dept., Faculty of Agric. Mansoura University

\begin{abstract}
Increasing potassium fertilizer rate up to $80 \mathrm{~kg} \mathrm{~K}_{2} \mathrm{O} / \mathrm{fed}$ significantly increased yield and improved its quality as well as increased the net income and investment rate. The highest values were obtained due to application of $40 \mathrm{~kg} \mathrm{~K} \mathrm{~K}_{2} \mathrm{O} / \mathrm{fed}$ in the first and second seasons as compared with untreated plants. Exogenous application of biostimulants, in particular, seaweed extract significantly increased yield and improved its quality as well as increased the net income and investment rate as compared to control in both seasons. Addition of effective microorganisms to the soil significantly increased yield and improved its quality as well as increased the net income and investment rate.

As for the interactions, application of biostimulants, in particular, seaweed extract, significantly increased yield and improved its quality as well as increased the net income and investment rate under all potassium fertilizer rates with or without an addition of effective microorganisms. The highest value was obtained under the treatment of $40 \mathrm{~kg} \mathrm{~K} 2 \mathrm{O} / \mathrm{fed}$ with an addition of effective microorganisms and spraying plants with $500 \mathrm{mg} / \mathrm{l}$ seaweed extract as compared to control plant during the first and second growing seasons.
\end{abstract}

\section{INTRODUCTION}

Potato (Solanum tuberosum L.) is a major source of inexpensive energy. It contains high levels of carbohydrates and significant amounts of vitamins $B$ and $C$ and other minerals (Pondey and Chadha 1996). It is an important crop in terms of human food and starch industry. In Egypt, the cultivated area is still small and difficult to disturb or to change the crop relation in the cultivated land. So, it must be pay attention to increase the productivity of the unit area of land. The production of the best fields requires that the soil must have favorable physical, chemical nutritional and biological conditions. Growers are continually seeking to overcome nutrient deficiencies as well as use improved management practices in order that yields may more nearly approach the genetic limit of crop plants.

Potato crop is a heavy remover of soil potassium and is the nutrient taken up in the greatest quantity; the tuber removes 1.5 times as much potassium as nitrogen and 4-5 times the amount of phosphate (Perrenoud 1993). Potassium increases the photosynthetic rate of crop leaves and carbon dioxide $\left(\mathrm{CO}_{2}\right)$ assimilation, and facilitates carbon movement (Sangakkara et al. 2000). Furthermore, $\mathrm{K}^{+}$plays an important role in the translocation of photosynthates from source to sink (Cakmak et al. 1994). 
Arafa A. A. et al.

Using biofertilizers in potato production in Egypt to produce safety yield and free of harmful chemicals and toxic materials is well recommended to take place in European market, and to have the consumer who is willing to pay high rate price for healthy safe product. Effective micro-organisms (EM) stock solution is one of many biofertilizers used in this concern. It contains a group of beneficial microorganisms (primary photosynthetic and lactic acid bacteria, yeast, actinomycetes and fermenting fungi) which are cultured and used to promote germination, flowering, fruiting and ripening in plants. Moreover, it improves physical, chemical and biological environments of the soil and enhances the photosynthetic capacity of crops.

Seaweed extracts (SE) (Ascophyllum nodosum Jol.) and humic acid (HA) are in common use as major components of vegetable and crop biostimulant formulations. Chemical analysis of seaweeds and their extracts have revealed the presence of a wide variety of plant growth regulators such as auxins and cytokinins in varying amounts (Zhang and Ervin 2004, 2008). Humic acid is considered to increase the permeability of plant membranes and enhance the uptake of nutrients. Moreover, humic acid is also considered to improve soil nitrogen uptake and encourage the uptake of potassium, calcium, magnesium and phosphorus, making these more mobile and available to plant root system (Pascual et al. 1999). In this concern, Ezzat et al. (2011) on potato plants, found that application of seaweed extract or humic acid plus $50 \%$ of recommended NPK significantly increased plant growth, yield and its components as well as tuber quality.

The aim of the present study was to find out the most favourable treatments producing more quality and quantity of potato yield. Furthermore, it was hoped that the results may lead to the utilization of one or more of the applied materials for large scale cultivation of potato under field condition.

\section{MATERIALS AND METHODS}

Two field experiments were conducted during the two successive winter seasons of 2007/2008 and 2008/2009 at the EL-Maniel village, Dakahlia Governorate to study the influence of effective microorganisms, biostimulants, and potassium levels as well as their combinations on the potato yield quantity and quality and its economic consideration.

Soil samples and analysis: Twenty surface samples $(0-20 \mathrm{~cm}$ depth) were taken at ten different locations. The mechanical and chemical analyses of the soil used were carried out in the two growing seasons and presented in Table (I).

Table (1):Mechanical and chemical soil characteristics at the experimental sites during 2007/2008 and 2008/2009

\begin{tabular}{|c|c|c|c|c|c|c|c|c|}
\hline \multirow{2}{*}{$\begin{array}{l}\text { Physical } \\
\text { properties }\end{array}$} & \multicolumn{2}{|c|}{ Value } & \multirow[b]{2}{*}{$\begin{array}{l}\text { Chemical } \\
\text { properties }\end{array}$} & \multicolumn{2}{|c|}{ Value } & \multirow{2}{*}{$\begin{array}{l}\text { Available } \\
\text { nutrients } \\
\left(\mathrm{mg} \mathrm{Kg}^{-1}\right)\end{array}$} & \multicolumn{2}{|c|}{ Value } \\
\hline & \begin{tabular}{|c|}
$1^{\text {st }}$ \\
season
\end{tabular} & $\begin{array}{c}2^{\text {nd }} \\
\text { season }\end{array}$ & & $\begin{array}{c}1^{\text {st }} \\
\text { season }\end{array}$ & $\begin{array}{c}2^{\text {nd }} \\
\text { season }\end{array}$ & & $\begin{array}{c}1^{\text {st }} \\
\text { season }\end{array}$ & $\begin{array}{c}2^{\text {nd }} \\
\text { season }\end{array}$ \\
\hline Sand \% & 21.0 & 21.1 & Field capacity \% & 32 & 33 & Nitrogen & 19 & 18 \\
\hline Silt\% & 32.3 & 33.0 & $\mathrm{EC}(\mathrm{dSm}-1)$ & 1.64 & 1.70 & phosphorous & 8 & 7 \\
\hline Clay \% & 46.0 & 45.8 & $\mathrm{pH}$ (Soil paste) & 7.82 & 7.75 & Potassium & 140 & 135 \\
\hline Soil texture & Clay & & Organic matter(\%) & 2.69 & 2.80 & & & \\
\hline
\end{tabular}


Plant Material, EM, Humic acid, and Seaweed Extract: Potatoes tubers; cV Spunta (imported from Holland) were used in the present investigation and obtained from Agric. Res. Center (ARC), Ministry of Agric., Egypt. Tubers were divided into pieces, averaging approximately $50 \mathrm{~g}$ weight. As recommended by the Pathology Dept. Ministry of Agric. Egypt, potato tubers pieces were sterilized with Vitavax Kapetan $1 \%$ at the rate of $1.25 \mathrm{~kg} / \mathrm{ton}$. Effective micro-organisms were used under the name of EM which consists of a mixed culture of beneficial micro-organisms primarily photosynthetic and lactic acid bacteria, yeast and streptomycetes. The number of each component was recorded in table (2)

Table (2): Components of EM used in the experiments

\begin{tabular}{|c|c|c|c|}
\hline Total bacterial & Lactic acid bacteria & Yeasts & Streptomycetes \\
\hline $2.5-9.6 \times 104 \mathrm{cfu} / \mathrm{ml}$ & $6.6-9.9 \times 106 \mathrm{cfu} / \mathrm{ml}$ & $105-106 \mathrm{cfu} / \mathrm{ml}$ & $8.5 \times 103 \mathrm{cfu} / \mathrm{ml}$ \\
\hline
\end{tabular}

Seaweed extract is derived by an alkaline hydrolysis procedure from the fresh, intact Ascophyllum nodosum and $100 \%$ soluble in cold water. Seaweeds contained all the trace elements and plant growth hormones, vitamins, amino acids, antibiotic and micronutrients (Crouch and Van Staden, 1993). Also seaweed extract contained protein/amino acids 3-5\%, lipid $1 \%$, alginic acid $12-18 \%$, fucose-containing polymers $12-15 \%$, mannitol $5-6 \%$, other carbohydrates $10-15 \%$ (Acadian Seaplants Limited, Dartmoth, Nova Scotia, Canada), As described by Fike et al., (2001).

Experimental design: Farm yard manure has been added during soil preparation in organic fertilization at dose $\left(40 \mathrm{~m}^{3} / \mathrm{fed}\right.$.). The experiment comprised of 18 treatments including three different rates of potassium fertilizers used individually or in combinations with $\mathrm{EM}$ and biostimulants (Humic acid at $150 \mathrm{mg} / \mathrm{l}$ or seaweed extract at $500 \mathrm{mg} / \mathrm{l}$ ). A randomized complete block design in factorial arrangement was used with three replicates. Each plot was $7.2 \mathrm{~m}^{2}\left(2.25 \times 3.20 \mathrm{~m}^{2}\right)$ included three ridges, each three meters long and $70 \mathrm{~cm}$ apart; the distance between hills was $30 \mathrm{~cm}$ apart.

Planting procedure: Potato tuber cv. Spunta was planted in the ridges at 12 $15 \mathrm{~cm}$ in depth $\left(30-40 \mathrm{~cm}\right.$ apart) on October $27^{\text {th }}$ in the first season $2007 / 2008$ and on November $9^{\text {th }}$ in the second season 2008/2009 respectively. Potassium $(K)$ levels occupied the main plots, while the effective microorganisms (EM) were assigned to the sub-plots, in each EM sub-plot the plants were divided into three groups which sprayed with either water (W), seaweed extract (SW) or humic acid (HA). The plot area was $7.2 \mathrm{~m}^{2}$ ridged $70 \mathrm{~cm}$ apart. As recommended by the Agric. Res. Center, Egypt, Nitrogen fertilizer was added at three equal portions, the 1st was applied after emergence (18-21 days from planting), in the form of ammonium sulphate $(20.5 \%)$, then two and four weeks later in the form of ammonium nitrate (33.5 $\%$ ) at the rate of $180 \mathrm{Kg} \mathrm{N} /$ fed. Phosphorous and potassium were applied during the soil preparation in the form of calcium superphosphate $(15.5 \%$ $\left.\mathrm{P}_{2} \mathrm{O}_{5}\right)$ and potassium sulphate $\left(48 \% \mathrm{~K}_{2} \mathrm{O}\right)$ at rate of $75 \mathrm{~kg} \mathrm{P}_{2} \mathrm{O}_{5} / \mathrm{fed}$ and 20 $\mathrm{kg} \mathrm{K}_{2} \mathrm{O}$ fed $^{-1}$ respectively. The respective EM treated plots received dilute EM solution 2 liter $/ \mathrm{m}^{2}$ before the first irrigation. Potassium fertilizers applied at three levels 0, 40 and $80 \mathrm{~kg} \mathrm{~K}_{2} \mathrm{O}$ fed $^{-1}$ using potassium sulphate $\left(48 \% \mathrm{~K}_{2} \mathrm{O}\right)$. 
Arafa A. A. et al.

The quantity was divided into two equal doses to be added before the first irrigation and before the second irrigation. Plants were sprayed with an aqueous solution of SW or HA two times at 60 and 75 days from planting. Irrigation was done immediately. All usual cultural practices of potatoes cultivation were carried out according to the procedures that recommended by the Ministry of Agric. Egypt. Harvesting was done after 115 days from planting dates in both seasons.

Sampling dates and data recorded: At harvest, which was carried out 115 days from planting a sample of 5 plants during the two growing seasons were chosen at random from each treatment to determine yield and its quality. Fresh tuber yield and its quality were recorded in terms of weight of tubers per plant and expected total yield per feddan (ton/fed) which was calculated according to the equation; total yield (ton/fed.)= (yield of experimental unit 'kg' $X$ net area of feddan ' $4000 \mathrm{~m}^{2}$ ) /area of experimental unit ' $\mathrm{m}^{2}$ '. Tuber quality (protein and ions percentage, soluble sugars, starch, organic acid, ascorbic acid, and phenol concentration as well as specific gravity and total soluble solid percentage) was determined as indicated below. Protein percentage "multiplying total nitrogen value with 6.25 will give the crude protein content'. For ion determination, ground tuber samples were wet digested with $\mathrm{HClO}_{3} / \mathrm{H}_{2} \mathrm{SO}_{4}$ until the solution was clear (Peterburgski, 1968), cooled, and brought to volume at $100 \mathrm{ml}$ using deionized water and kept for determinations. Nitrogen was determined calorimetrically by Nessler's methods as described by Gedroits (1963), phosphorous was determined spectrophotometrically (Spekol 11, Uk) by the methods described by Cooper (1977) using ammonium molybdate and ascorbic acid. Potassium was determined by Jenway Flamephotometer model CORNING 400 (UK) (Peterburgski, 1968). Soluble sugars and starch were estimated following Malik and Srivastava (1979). For the estimation of soluble sugars and starch, $0.1 \mathrm{~g}$ of well ground dry materials was homogenized in $80 \%$ ethanol and centrifuged, the residue was retained which was repeatedly washed with $80 \%$ ethanol to remove all traces of soluble sugars. The filtrate thus obtained was used for the determination of soluble sugars. The residue was used for the determination of starch. Five $\mathrm{ml}$ of distilled water and $6.5 \mathrm{ml}$ of $52 \%$ perchloric acid were added to the residue. Extraction of starch with perchloric acid was carried out at $0{ }^{\circ} \mathrm{C}$ for $20 \mathrm{~min}$, and then centrifuged, and the extract was retained. With the residue, the above step was repeated using fresh perchloric acid and the extract of this step was combined with the extract of the first step and then the volumes of each of the sugar and starch extracts were made up to $100 \mathrm{ml}$ by the addition of distilled water. The extracts for both soluble sugars and starch $(0.1 \mathrm{ml})$ were determined by the phenolsulphoric acid methods using spectrophotometer (Spekol 11, Uk) as described by Sadasivam and Manickam, (1996).

Specific gravity was calculated according to Abdel-Aal (1971) as follows: Specific gravity $\left(\mathrm{g} / \mathrm{cm}^{3}\right)=$ Tuber mass $(\mathrm{g}) /$ tuber volume $\left(\mathrm{cm}^{3}\right)$; TSS was determined in potato juice by refractometer according to AOAC (1990). Total organic acids in potato tuber, were extracted from frozen tuber with distilled water then filtered through filter paper. A known volume from the filtrate was transferred in vials and determined by titration with $\mathrm{NaOH}$ using 
PHTH as an indicator. Ascorbic acid was extracted from plant material (tuber) with oxalic acid then titrate using 2.6- Dichlorophenol indophenole as described by Sadasivam and Manickam (1996).Potato tuber samples were extracted with $80 \%$ cold ethanol $(\mathrm{v} / \mathrm{v})$ for three times at $0^{\circ} \mathrm{C}$, then put it in water bath for $30 \mathrm{~min}$. The combined extracts were collected and filtered through whatman No 1 filter paper. Then the volume of sample was raised up to $10 \mathrm{ml}$ with cold ethanol. Total phenolic content in the potato tuber extracts were determined with Folin-Ciocalteu reagent by the of Slinkard and Singleton method (1977) using catecole as a standard phenolic compound. Briefly, $1 \mathrm{ml}$ of extract solution was mixed with distilled water. One $\mathrm{ml}$ of Folin-Ciocalteu reagent was added to the content of the flask and mixed thoroughly. After $3 \mathrm{~min}, 3 \mathrm{ml}$ of $\mathrm{Na}_{2} \mathrm{CO}_{3}$ was added then the mixture was allowed to stand for $2 \mathrm{~h}$. The absorbance was measured at $660 \mathrm{~nm}$. The concentration of total phenolic compounds in the extracts was determined as microgram of catecol equivalent by using an equation that was obtained from the standard catecol acid graph.

Economic and Statistical analysis: Data were subjected to statistical analysis of variance according to Norman and Streiner (2003). LSD value was used to test the difference between treatment means at $5 \%$. For economic analysis, after considering the cost of fertilizer and all chemical used, the incomes from potato yield were used for economic analysis. Net income (NI) generated by a crop was the amount of money left when total costs (TC) were subtracted from total return (TR). $\mathrm{NI}=\mathrm{TR}-\mathrm{TC}$. TR corresponds to the value of the harvested crop. TC includes the costs of all inputs, such as seed potatoes, fertilizer, pesticides, labour and capital. The variable component in the total costs was $\mathrm{K}$ fertilizers, effective microorganisms and biostimulants.

\section{RESULTS}

Tuber yield:

Data illustrated in Figure (1 and 2) indicate that, tuber yield (measured as tubers yield $(\mathrm{kg})$ per plant and total yield (ton/fed.) during the two growing seasons were significantly increased with increasing potassium fertilizer rate up to $40 \mathrm{~kg} \mathrm{~K}{ }_{2} \mathrm{O} / \mathrm{fed}$, thereafter decreased but still higher than that of the control plants $(20 \mathrm{~kg} \mathrm{~K} 2 \mathrm{O} / \mathrm{fed})$.

Bio-fertilization exerted positive effects in this respect. An addition of effective microorganisms in both seasons significantly increased tuber yield per plant and tuber yield per fed. in both growing seasons. Regarding the effect of biostimulants on potato yield, the data illustrated in Figures (1 and 2) proved that, foliar application of biostimulants; in particular, seaweed extract at $500 \mathrm{mg} / \mathrm{l}$ significantly increased the yield of potato plants represented as tuber yield per plant and per fed. In this regard, application of seaweed extract increased tuber yield per plant from 0.902 and 1.041 to 1.275 and $1.491 \mathrm{~kg}$. and tuber yield per fed from 9.936 and 10.416 to 13.844 and 14.916 ton in both growing season respectively. With respect to the interaction effects, the data in tables ( 3 and 4 ) showed an additive effect on potato tuber yield parameters during the two growing seasons compared with the corresponding control. In this concern, tubers yield per plant was 
Arafa A. A. et al.

significantly increased when the plants inoculated with effective microorganisms under addition of potassium fertilizers from 20 to $80 \mathrm{~kg}$ $\mathrm{K} 2 \mathrm{O} /$ feddan and spraying plants with biostimulants, in particular, seaweed extract.

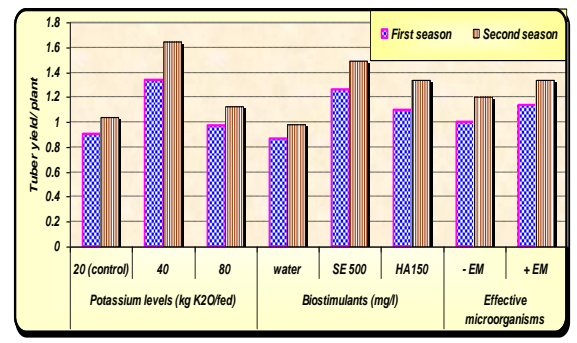

Figure (1): Tuber yield per potato plant $(\mathrm{Kg})$ as affected by potassium fertilizer, biostimulants or effective microorganisms in both growing season

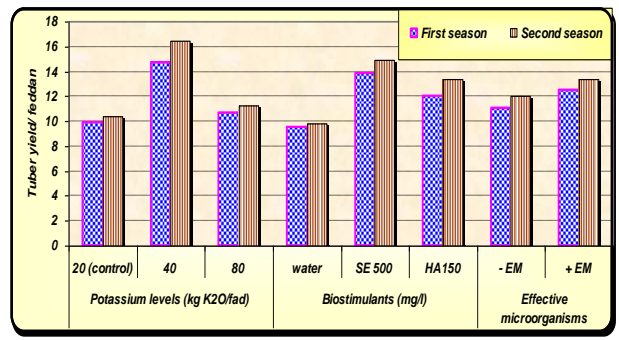

Figure (2): Tuber yield per feddan (ton) as affected by potassium fertilizer, biostimulants or effective microorganisms in both growing season (SE, Seaweed extract; HA, Humic acid)

Table (3):Tuber yield per potato plant $(\mathrm{kg})$ as affected by the interactions between potassium fertilizer (A), effective microorganisms (B) and biostimulants (C) during the two growing season

\begin{tabular}{|c|c|c|c|c|c|c|}
\hline \multirow{3}{*}{ Treatment } & \multicolumn{6}{|c|}{ First season } \\
\hline & \multicolumn{3}{|c|}{ - EM } & \multicolumn{3}{|c|}{ + EM } \\
\hline & $\mathrm{K}_{20}$ & $\mathrm{~K}_{40}$ & $\mathrm{~K}_{80}$ & $\mathrm{~K}_{20}$ & $\mathrm{~K}_{40}$ & $\mathrm{~K}_{80}$ \\
\hline Water & 0.717 & 0.939 & 0.818 & 0.808 & 1.060 & 0.838 \\
\hline SE & 0.979 & 1.484 & 0.990 & 1.040 & 1.879 & 1.171 \\
\hline $\mathrm{HA}$ & 0.879 & 1.313 & 0.929 & 0.990 & 1.363 & 1.101 \\
\hline LSD 5\% & \multicolumn{2}{|l|}{ A 0.047} & 114 & \multicolumn{2}{|c|}{ C 0.023} & ABC 0.057 \\
\hline \multicolumn{7}{|c|}{ Second season } \\
\hline Water & 0.783 & 1.166 & 0.866 & 0.850 & 1.283 & 0.933 \\
\hline SE & 1.166 & 1.849 & 1.166 & 1.199 & 2.183 & 1.383 \\
\hline $\mathrm{HA}$ & \begin{tabular}{l|l}
1.066 & \\
\end{tabular} & 1.633 & 1.116 & 1.183 & 1.750 & 1.300 \\
\hline LSD 5\% & A 0.082 & \multicolumn{2}{|c|}{ B 0.013} & C 0.02 & \multicolumn{2}{|c|}{ ABC 0.070} \\
\hline
\end{tabular}

( $\mathrm{K}_{20}, 20 \mathrm{~kg} \mathrm{~K} \mathrm{~K}_{2} \mathrm{O}$ fed; $\mathrm{K}_{40}, 40 \mathrm{~kg} \mathrm{~K} \mathrm{~K}_{2} \mathrm{O}$ fed; $\mathrm{K}_{80}, 80 \mathrm{~kg} \mathrm{~K} \mathrm{O} /$ fed; SE, seaweed extract; HA, humic acid)

Data in the same tables showed that, plants inoculated with effective microorganisms and received $40 \mathrm{~kg} \mathrm{~K} \mathrm{~K}_{2} \mathrm{O}$ per fed. then shoot spraying with seaweed extract gave higher values than that of control plants. This treatment significantly increased tuber yield per plant from 0.717 and 0.783 $\mathrm{kg}$ to 1.879 and $2.183 \mathrm{~kg}$ and tuber yield per fed. from 7.880 and 7.833 ton to 20.657 and 21.833 ton in both growing seasons respectively. It is worth mentioning that, an addition of $40 \mathrm{~kg} \mathrm{~K} 2 \mathrm{O} / \mathrm{fed}$ may be substituted by the inoculation with effective microorganisms and spraying plants with seaweed extract when used in combinations without significant reduction in the tuber yield. 
Table (4):Tuber yield per fed. (ton) as affected by the interactions between potassium fertilizer (A), effective microorganisms (B) and biostimulants $(\mathrm{C})$ during the two growing season

\begin{tabular}{|c|c|c|c|c|c|c|}
\hline \multirow{3}{*}{ Treatment } & \multicolumn{6}{|c|}{ First season } \\
\hline & \multicolumn{3}{|c|}{ - EM } & \multicolumn{3}{|c|}{$+\mathrm{EM}$} \\
\hline & $\mathrm{K}_{20}$ & $\mathrm{~K}_{40}$ & $\mathrm{~K}_{80}$ & $\mathrm{~K}_{20}$ & $\mathrm{~K}_{40}$ & $\mathrm{~K}_{80}$ \\
\hline Water & 7.880 & 10.327 & 8.993 & 8.880 & 11.657 & 9.217 \\
\hline SE & 10.770 & 16.327 & 10.880 & 11.550 & 20.657 & 12.880 \\
\hline $\mathrm{HA}$ & 9.657 & 14.437 & 10.217 & 10.880 & 14.997 & 12.107 \\
\hline LSD 5\% & \multicolumn{2}{|l|}{ A 0.578} & 144 & \multicolumn{2}{|c|}{ C 0.259} & $\mathrm{ABC} 0.634$ \\
\hline \multicolumn{7}{|c|}{ Second season } \\
\hline Water & 7.833 & 11.666 & 8.666 & 8.499 & 12.833 & 9.333 \\
\hline SE & 11.666 & 18.499 & 11.666 & 11.999 & 21.833 & 13.833 \\
\hline $\mathrm{HA}$ & 10.666 & 16.333 & 11.166 & 11.833 & 17.499 & 12.999 \\
\hline LSD 5\% & \multicolumn{2}{|l|}{ A 0.829} & 130 & \multicolumn{2}{|l|}{ C 0.287} & $\mathrm{BC} 0.703$ \\
\hline
\end{tabular}

$\left(\mathrm{K}_{20}, 20 \mathrm{~kg} \mathrm{~K} \mathrm{~K}_{2} \mathrm{O}\right.$ fed; $\mathrm{K}_{40}, 40 \mathrm{~kg} \mathrm{~K} \mathrm{~K}_{2} \mathrm{O}$ fed; $\mathrm{K}_{80}, 80 \mathrm{~kg} \mathrm{~K} / \mathrm{O}$ fed; SE, seaweed extract; HA humic acid)

\section{Tuber quality:}

Total soluble solids (TSS), total acidity, and specific gravity: The effects of EM, biostimulants and potassium fertilizers as well as their combinations on the percentages of total soluble solids, total acidity and specific gravity of potato tubers during the second season are illustrated in figures $(3,4,5)$ and presented in Table (5). Data revealed that studied characteristics were significantly affected by the application of EM, biostimulants and potassium fertilizers. The figures indicate that potassium fertilizer rate at $40 \mathrm{~kg} \mathrm{~K} 2 \mathrm{O} / \mathrm{fed}$ gave the highest values of total soluble solids, total acidity and specific gravity $(6.533 \%, 5.973 \mathrm{mg} / \mathrm{g} \mathrm{FW}$ and 1.117 respectively) as compared with $20 \mathrm{~kg} \mathrm{~K} 2 \mathrm{O} / \mathrm{fed}$ represented as control plant $(5.639 \%, 3.623 \mathrm{mg} / \mathrm{g} \mathrm{FW}$ and 1.117 respectively).

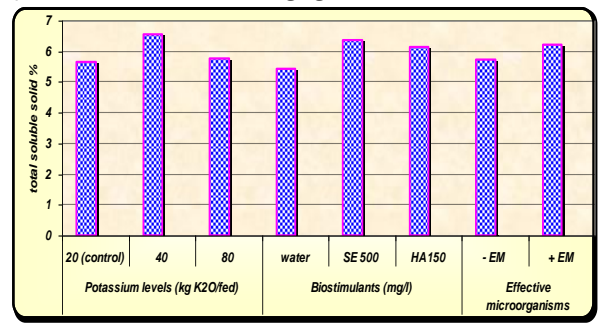

Figure (3): Total soluble solid of potato tuber as affected by potassium fertilizer, biostimulants or effective microorganisms in the second season

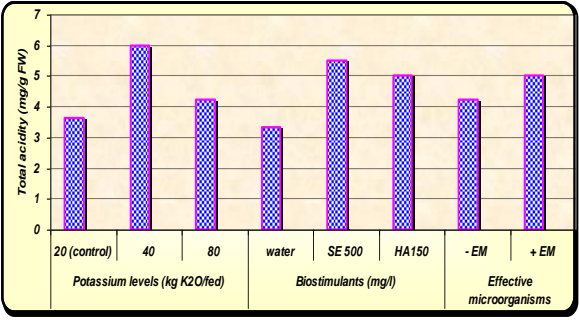

Figure (4): Total acidity of potato tuber as affected by potassium fertilizer, biostimulants or effective microorganisms in the second season (SE, Seaweed extract; HA, Humic acid) 


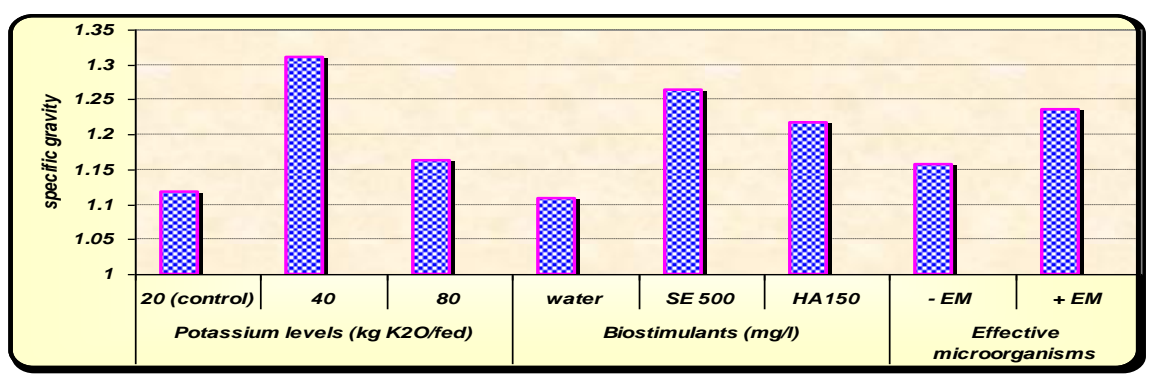

Figure (5): Specific gravity of potato tuber as affected by potassium fertilizer, biostimulants or effective microorganisms in the second season (SE, Seaweed extract; HA, Humic acid)

The data illustrated in the same figures clearly showed that application of both biostimulants significantly increased all studied characteristics as compared with untreated plants. The most effective treatment in this concern was seaweed extract which gave the highest values of total soluble solid percentage, total acidity $(\mathrm{mg} / \mathrm{g} \mathrm{FW}$ ) and specific gravity $(6.361,5.505$ and 1.264 respectively) as compared with control plants (5.417, 3.327 and 1.108 respectively). Inoculated potato plants with effective microorganisms increased total soluble solids, total acidity and specific gravity from $5.741,4.22$ and 1.157 to $6.201,5.01$ and 1.236 respectively.

Table (5): Total soluble solids, total acidity and specific gravity in potato tuber as affected by the interactions between potassium fertilizer (A), effective microorganisms (B) and biostimulants (C) at 115 days from planting during the second season

\begin{tabular}{|c|c|c|c|c|c|c|}
\hline \multirow{3}{*}{ Treatment } & \multicolumn{6}{|c|}{ Total soluble solid } \\
\hline & \multicolumn{3}{|c|}{ - EM } & \multicolumn{3}{|c|}{+ EM } \\
\hline & $\mathrm{K}_{20}$ & $\mathrm{~K}_{40}$ & $\mathrm{~K}_{80}$ & $\mathrm{~K}_{20}$ & $\mathrm{~K}_{40}$ & $\mathrm{~K}_{80}$ \\
\hline Water & 4.833 & 5.500 & 5.167 & 5.333 & 6.333 & 5.333 \\
\hline SE & 6.000 & 7.000 & 6.000 & 6.167 & 6.833 & 6.167 \\
\hline $\mathrm{HA}$ & \begin{tabular}{l|l}
5.167 & \\
\end{tabular} & 6.500 & 5.500 & 6.333 & 7.033 & 6.333 \\
\hline LSD 5\% & \multirow{2}{*}{\multicolumn{2}{|c|}{ A 0.4852}} & 0.3152 & \multirow{2}{*}{\multicolumn{2}{|c|}{ C 0.3409}} & ABC NS \\
\hline \multicolumn{3}{|c|}{ Total acidity } & & & & \\
\hline Water & 2.434 & 4.017 & 2.800 & 2.434 & 5.113 & 3.165 \\
\hline SE & 4.139 & 6.696 & 4.383 & 4.748 & 7.227 & 5.844 \\
\hline $\mathrm{HA}$ & 3.530 & 6.331 & 3.652 & 4.505 & 6.452 & 5.600 \\
\hline LSD 5\% & \multicolumn{2}{|l|}{ A 0.1197} & 0.0896 & \multicolumn{2}{|c|}{ C 0.1120} & ABC 0.2743 \\
\hline \multicolumn{7}{|c|}{ Specific gravity } \\
\hline Water & 1.047 & 1.111 & 1.076 & 1.052 & 1.234 & 1.127 \\
\hline SE & 1.116 & 1.359 & 1.174 & 1.206 & 1.471 & 1.261 \\
\hline $\mathrm{HA}$ & \begin{tabular}{l|l}
1.103 & \\
\end{tabular} & 1.326 & 1.105 & 1.178 & 1.358 & 1.234 \\
\hline LSD 5\% & A 0.1366 & \multicolumn{2}{|c|}{ B NS } & C 0.07 & \multicolumn{2}{|c|}{ ABC NS } \\
\hline
\end{tabular}

$\left(\mathrm{K}_{20}, 20 \mathrm{~kg} \mathrm{~K} \mathrm{~K}_{2} \mathrm{O}\right.$ fad; $\mathrm{K}_{40}, 40 \mathrm{~kg} \mathrm{~K} \mathrm{~K}_{2} \mathrm{O}$ fad; $\mathrm{K}_{80}, 80 \mathrm{~kg} \mathrm{~K} \mathrm{O} / \mathrm{fad}$; SE, seaweed extract; HA humic acid)

Regarding the interaction effects between potassium fertilizer rate, biostimulants spraying and effective microorganisms inoculation, the data presented in Table (5) indicated that all combinations insignificantly increased 
total soluble solids and specific gravity. Meanwhile, they significantly increased total acidity in potato tuber. The most effective in this concern was inoculation with effective microorganisms and addition of $40 \mathrm{~kg} \mathrm{~K} 2 \mathrm{O} / \mathrm{fed}$ as well as spraying plant shoots with humic acid which increased total soluble solids from 4.833 to reach 7.033 . On the other hand, the highest values for total acidity and specific gravity were obtained due to addition of $40 \mathrm{~kg}$ $\mathrm{K}_{2} \mathrm{O} / \mathrm{fed}$ and inoculated potato plants with effective microorganisms beside the foliar spraying with seaweed extract. This treatment increased total acidity and specific gravity from 2.434 and 1.047 to 7.227 and 1.471 respectively.

Crude protein, ascorbic acid, phenol, soluble sugars and starch: The effects of potassium fertilizer rates, inoculation with effective microorganisms and/or biostimulants foliar application as well as their interactions on crude protein (\%), ascorbic acid concentration $(\mathrm{mg} / \mathrm{g} \mathrm{FW})$, phenol concentration ( $\mathrm{mg} / \mathrm{g} \mathrm{FW})$, soluble sugars concentration $(\mathrm{mg} / \mathrm{g} \mathrm{FW}$ ) and starch concentration $(\mathrm{mg} / \mathrm{g} \mathrm{FW}$ ) of potato tubers plants during the second season are illustrated in figures (6-10) and presented in Tables (6 and 7).

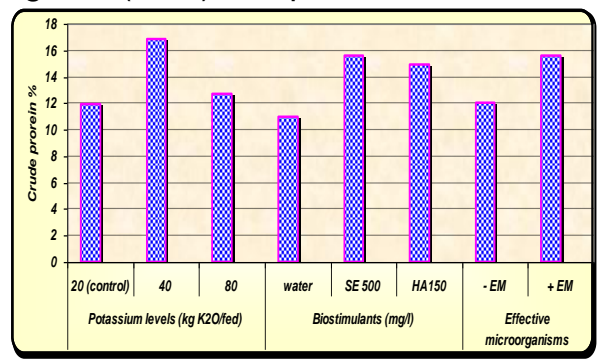

Figure(6): Crude protein percentage in potato tuber as affected by potassium fertilizer, biostimulants or effective microorganisms in the second season

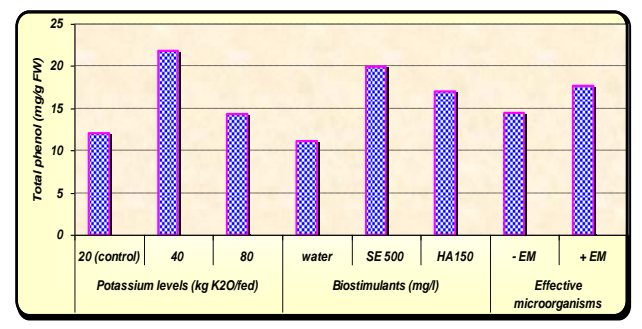

Figure(8): $\quad$ Total phenol concentration $(\mathrm{mg} / \mathrm{gFW})$ in potato tuber as affected by potassium fertilizer, biostimulants or effective microorganisms in the second season

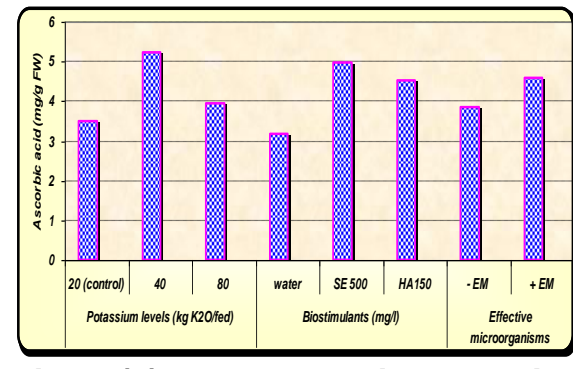

Figure(7): Ascorbic acid concentration $(\mathrm{mg} / \mathrm{gFW})$ in potato tuber as affected by potassium fertilizer, biostimulants or effective microorganisms in the second season

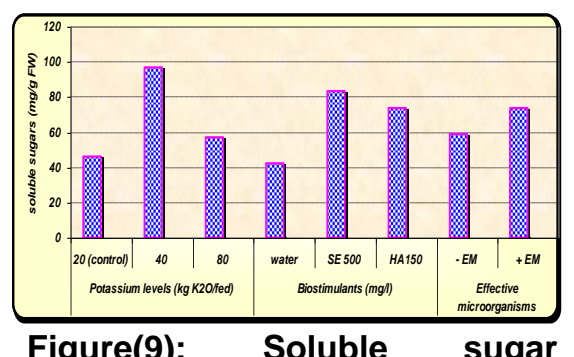

Figure(9): Soluble sugar concentration $(\mathrm{mg} / \mathrm{g} \mathrm{FW})$ in potato tuber as affected by potassium fertilizer, biostimulants or effective microorganisms in the second season 


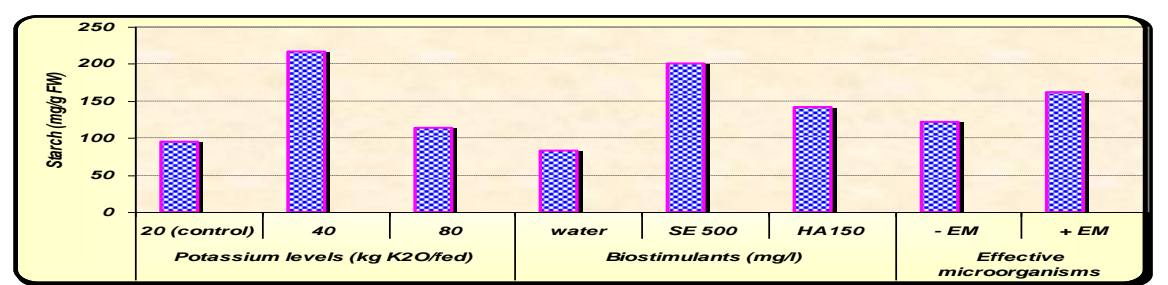

Figure (10): Starch concentration ( $\mathrm{mg} / \mathrm{g} \mathrm{FW}$ ) in potato tuber as affected by potassium fertilizer, biostimulants or effective microorganisms in the second season (SE, Seaweed extract; HA, Humic acid)

It is well noted from the figures that an addition of potassium fertilizer rate increased significantly crude protein percentage, ascorbic acid concentration, phenol concentration, soluble sugars concentration and starch concentration in potato tuber. The highest value for the quality characteristics was obtained due to addition of $40 \mathrm{Kg} \mathrm{K}$ O/fed as compared with control plants having $20 \mathrm{Kg} \mathrm{K} 2 \mathrm{O} / \mathrm{fed}$. Regarding the beneficial effects of biostimulants on crude protein percentage and concentration of ascorbic acid, phenol, soluble sugars and starch in potato tuber, the same figures clearly showed that application of biostimulants, in particular seaweed extract significantly increased the studied characteristics from $10.940 \%, 3.181 \mathrm{mg} / \mathrm{g} \mathrm{FW}, 11.093$ $\mathrm{mg} / \mathrm{g} \mathrm{FW}, 42.253 \mathrm{mg} / \mathrm{g} \mathrm{FW}$ and $83.516 \mathrm{mg} / \mathrm{g} \mathrm{FW}$ to $14.913 \%, 4.515 \mathrm{mg} / \mathrm{g}$ FW, $17.038 \mathrm{mg} / \mathrm{g}$ FW, $74.029 \mathrm{mg} / \mathrm{g} \mathrm{FW}$ and $142.378 \mathrm{mg} / \mathrm{g} \mathrm{FW}$ respectively. Also, the inoculation of potato plants with effective microorganisms improved the potato quality due to a significant increase in all tuber quality characteristics under investigation.

Table (6): Crude protein percentage, phenol concentration (mglg FW), ascorbic acid concentration ( $\mathrm{mg} / \mathrm{g} \mathrm{FW}$ ) in potato tuber as affected by the interactions between potassium fertilizer (A), effective microorganisms (B) and biostimulants (C) at 115 days from planting during the second season

\begin{tabular}{|c|c|c|c|c|c|c|}
\hline \multirow{3}{*}{ Treatment } & \multicolumn{6}{|c|}{ Crude protein \% } \\
\hline & \multicolumn{3}{|c|}{ - EM } & \multicolumn{3}{|c|}{+ EM } \\
\hline & \multicolumn{2}{|r|}{$\mathrm{K}_{40}$} & $\mathrm{~K}_{80}$ & \multicolumn{3}{|c|}{$\frac{+}{\mathrm{C}_{40}}$} \\
\hline Water & 8.975 & 10.570 & 9.674 & 9.463 & 16.768 & 10.188 \\
\hline SE & 10.873 & 18.548 & 11.388 & 16.545 & 18.841 & 17.506 \\
\hline $\mathrm{HA}$ & \begin{tabular}{l|l}
10.096 & \\
\end{tabular} & 17.888 & 10.188 & 15.515 & 18.416 & 17.374 \\
\hline LSD 5\% & \multicolumn{2}{|l|}{ A 2.5652} & 31.1140 & \multicolumn{2}{|c|}{ C 1.8246} & ABC 4.4692 \\
\hline \multicolumn{7}{|c|}{ Phenol concentration (mg/g FW) } \\
\hline Water & 7.456 & 13.288 & 9.699 & 8.757 & 16.900 & 10.461 \\
\hline SE & 13.871 & 25.670 & 14.252 & 15.845 & 29.259 & 20.825 \\
\hline $\mathrm{HA}$ & \begin{tabular}{l|l}
11.763 & \\
\end{tabular} & 21.117 & 12.570 & 14.320 & 24.212 & 18.247 \\
\hline LSD 5\% & \multicolumn{2}{|c|}{\begin{tabular}{|l|l|} 
A 0.3537 & \\
\end{tabular}} & 30.3457 & \multicolumn{2}{|c|}{ C 0.4731} & ABC 1.1588 \\
\hline \multicolumn{7}{|c|}{ Ascorbic acid concentration (mg/g FW) } \\
\hline Water & \begin{tabular}{l|l}
2.422 & \\
\end{tabular} & 3.755 & 2.700 & 2.555 & 4.711 & 2.944 \\
\hline SE & 3.944 & 5.722 & 4.166 & 4.533 & 6.155 & 5.278 \\
\hline $\mathrm{HA}$ & \begin{tabular}{l|l}
3.133 & \\
\end{tabular} & 5.400 & 3.500 & 4.333 & 5.600 & 5.122 \\
\hline LSD 5\% & \multicolumn{2}{|l|}{ A 0.1472} & 0.0647 & \multicolumn{2}{|c|}{ C 0.0890} & ABC 0.2183 \\
\hline
\end{tabular}

( $\mathrm{K}_{20}, 20 \mathrm{~kg} \mathrm{~K} \mathrm{O} / \mathrm{fed}$; $\mathrm{K}_{40}, 40 \mathrm{~kg} \mathrm{~K}$ O/ fed; $\mathrm{K}_{80}, 80 \mathrm{~kg} \mathrm{~K} \mathrm{O} / \mathrm{fed}$; SE, seaweed extract; HA humic acid) 
As regard to the interaction effects between potassium fertilizer rate, effective microorganisms and foliar application of biostimulants on crude protein percentage, and the concentration of phenol, ascorbic acid, soluble sugars and starch in potato tuber, the data presented in Tables (6 and 7) revealed that an addition of $40 \mathrm{Kg} \mathrm{K} 2 \mathrm{O} / \mathrm{fed}$ as soil addition plus inoculation with effective microorganisms therafer, spraying the plants with seaweed extracts gave the highest values of studied characteristics as compared with untreated plants. since it significantly increased crude protein percentage, phenol concentration, ascorbic acid concentration, and soluble sugar as well as starch concentrations from $8.975 \%, 7.456 \mathrm{mg} / \mathrm{g} \mathrm{FW}, 2.422 \mathrm{mg} / \mathrm{g} \mathrm{FW}$, $29.276 \mathrm{mg} / \mathrm{g} \mathrm{FW}$ and $50.793 \mathrm{mg} / \mathrm{g} \mathrm{FW}$ to $18.841 \%, 29.259 \mathrm{mg} / \mathrm{gFW}, 6.155$ $\mathrm{mg} / \mathrm{g} \mathrm{FW}, 124.79 \mathrm{mg} / \mathrm{g} \mathrm{FW}$ and $364.94 \mathrm{mg} / \mathrm{g} \mathrm{FW}$ respectively.

Table (7):Soluble sugars concentration (mglg FW) and starch concentration $(\mathrm{mg} / \mathrm{g} \mathrm{FW})$ in potato tuber as affected by the interactions between potassium fertilizer (A), effective microorganisms (B) and biostimulants (C) at 115 days from planting during the second season

\begin{tabular}{|c|c|c|c|c|c|c|}
\hline \multirow{3}{*}{ Treatment } & \multicolumn{6}{|c|}{ Soluble sugars (mg/g FW) } \\
\hline & \multicolumn{3}{|c|}{ - EM } & \\
\hline & \multicolumn{2}{|r|}{$\mathrm{K}_{40}$} & $\mathrm{~K}_{80}$ & \multicolumn{2}{|r|}{+ + EM } & \\
\hline Water & 29.276 & 50.071 & 34.359 & 32.491 & 67.670 & 39.654 \\
\hline SE & 51.765 & 117.32 & 56.579 & 62.914 & 124.79 & 88.695 \\
\hline $\mathrm{HA}$ & 41.676 & 106.77 & 44.949 & 60.083 & 113.60 & 77.086 \\
\hline LSD 5\% & \multicolumn{2}{|c|}{\begin{tabular}{|l|l|} 
A 2.0226 & \\
\end{tabular}} & 3155 & \multicolumn{2}{|c|}{ C 1.4802} & ABC 3.6259 \\
\hline \multicolumn{7}{|c|}{ Starch $(\mathrm{mg} / \mathrm{g} \mathrm{FW})$} \\
\hline Water & 50.793 & 104.19 & 64.040 & 62.114 & 148.68 & 71.280 \\
\hline SE & 114.64 & 279.38 & 122.80 & 136.44 & 364.94 & 182.18 \\
\hline $\mathrm{HA}$ & 78.673 & 195.97 & 84.450 & 129.96 & 206.05 & 159.15 \\
\hline LSD 5\% & \multicolumn{2}{|c|}{ A 20.305} & 2133 & C 9.287 & \multicolumn{2}{|c|}{ ABC 22.750} \\
\hline
\end{tabular}

$\left(\mathrm{K}_{20}, 20 \mathrm{~kg} \mathrm{~K}_{2} \mathrm{O} /\right.$ fed; $\mathrm{K}_{40}, 40 \mathrm{~kg} \mathrm{~K}{ }_{2} \mathrm{O} /$ fed; $\mathrm{K}_{80}, 80 \mathrm{~kg} \mathrm{~K} \mathrm{~K}_{2} \mathrm{O}$ / fed; SE, seaweed extract; $\mathrm{HA}$ humic acid)

Ion percentage in the tubers: The effects of potassium fertilizer and/or effective microorganisms on nitrogen, phosphorus and potassium percentages in potato tubers at harvesting; 105 days from planting during the second growing season are illustrated in figures $(10,11,12)$ and presented in table (8).

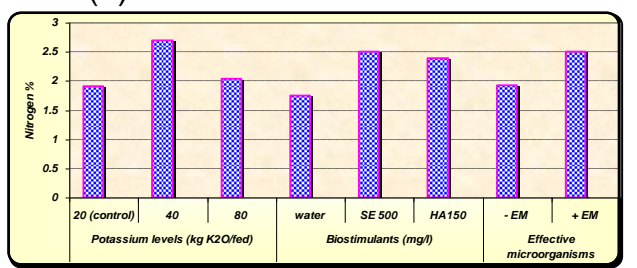

Figure (11): Nitrogen percentage in potato tuber as affected by potassium fertilizer, biostimulants or effective microorganisms in the second season

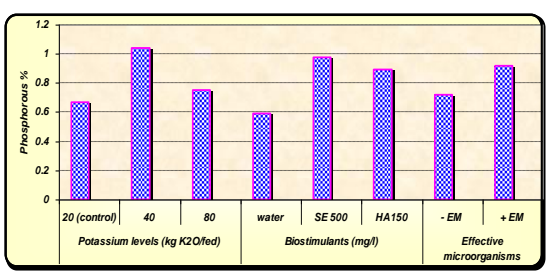

Figure (12): Phosphorous percentage in potato tuber as affected by potassium fertilizer, biostimulants or effective microorganisms in the second season 


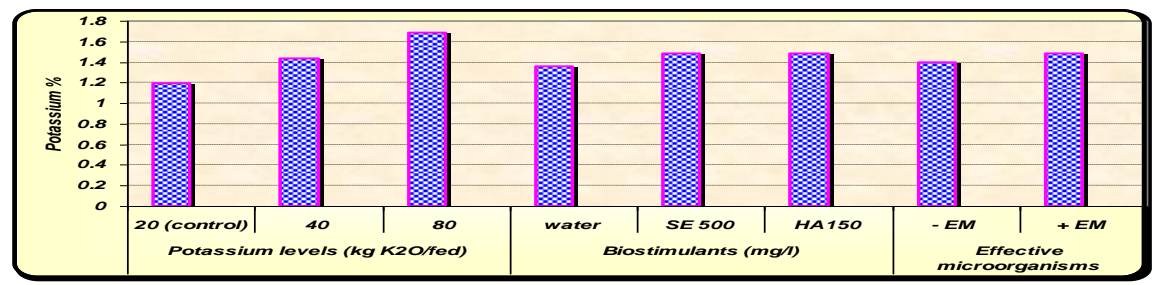

Figure (13): Potassium percentage in potato tuber as affected by potassium fertilizer, biostimulants or effective microorganisms in the second season (SE, Seaweed extract; HA, Humic acid)

The data indicated that increasing potassium fertilizer rates from 20 to $80 \mathrm{~kg} \mathrm{~K} \mathrm{~K}_{2} \mathrm{O} / \mathrm{fed}$ significantly increased nitrogen, phosphorous and potassium percentages in potato tuber, and the highest values for nitrogen and phosphorous percentage were obtained due to an addition of $40 \mathrm{~kg}$ $\mathrm{K}_{2} \mathrm{O} / \mathrm{fed}$. On the other hand, the highest potassium percentage was obtained due to an addition of the highest rate of potassium fertilizer $\left(80 \mathrm{~kg} \mathrm{~K}{ }_{2} \mathrm{O} / \mathrm{fed}\right)$. Concerning the effects of foliar spraying with either seaweed extract or humic acid on tuber ion percentage comparing with control, the figures $(10,11,12)$ clearly showed that foliar application of biostimulants significantly increased ion percentage in potato tuber.

Table (8): Nitrogen, potassium and phosphorous percentage in potato tuber as affected by the interactions between potassium fertilizer (A), effective microorganisms (B) and biostimulants (C) during the second season (SE, Seaweed extract; HA, Humic acid)

\begin{tabular}{|c|c|c|c|c|c|c|}
\hline \multirow{3}{*}{ Treatment } & \multicolumn{6}{|c|}{ Nitrogen } \\
\hline & \multicolumn{3}{|c|}{ - EM } & \multicolumn{3}{|c|}{$+E M$} \\
\hline & $\mathrm{K}_{20}$ & $\mathrm{~K}_{40}$ & $\mathrm{~K}_{80}$ & $\mathrm{~K}_{20}$ & $\mathrm{~K}_{40}$ & $K_{80}$ \\
\hline Water & 1.436 & 1.691 & 1.548 & 1.514 & 2.683 & 1.630 \\
\hline SE & 1.739 & 2.967 & 1.822 & 2.647 & 3.014 & 2.801 \\
\hline $\mathrm{HA}$ & 1.615 & 2.862 & 1.630 & 2.482 & 2.979 & 2.780 \\
\hline LSD 5\% & \multicolumn{2}{|l|}{ A 0.3988} & 1761 & C 0.28 & & .7099 \\
\hline \multicolumn{7}{|c|}{ Phosphorous } \\
\hline Water & 0.434 & 0.693 & 0.453 & 0.448 & 1.014 & 0.519 \\
\hline SE & 0.708 & 1.134 & 0.773 & 0.984 & 1.193 & 1.050 \\
\hline $\mathrm{HA}$ & 0.517 & 1.076 & 0.672 & 0.923 & 1.120 & 1.025 \\
\hline LSD 5\% & \multicolumn{2}{|l|}{ A 0.0671} & 0314 & C 0.050 & & .1243 \\
\hline \multicolumn{7}{|c|}{ Potassium } \\
\hline Water & 1.044 & 1.346 & 1.539 & 1.128 & 1.414 & 1.649 \\
\hline SE & 1.212 & 1.439 & 1.649 & 1.321 & 1.481 & 1.800 \\
\hline $\mathrm{HA}$ & \begin{tabular}{l|l}
1.178 &
\end{tabular} & 1.464 & 1.716 & 1.304 & 1.472 & 1.750 \\
\hline LSD 5\% & \multicolumn{2}{|l|}{ A 0.0553} & B NS & C 0.033 & \multicolumn{2}{|c|}{ ABC NS } \\
\hline
\end{tabular}

$\left(\mathrm{K}_{20}, 20 \mathrm{~kg} \mathrm{~K} \mathrm{~K}_{2} \mathrm{O}\right.$ fed; $\mathrm{K}_{40}, 40 \mathrm{~kg} \mathrm{~K} \mathrm{~K}_{2} \mathrm{O} / \mathrm{fed} ; \mathrm{K}_{80}, 80 \mathrm{~kg} \mathrm{~K} \mathrm{~K}_{2} \mathrm{O}$ fed; SE, seaweed extract; HA humic acid)

The highest percentage of ions in potato tuber was obtained due to spraying potato shoot with seaweed extract. This treatment increased nitrogen, phosphorous and potassium percentages from $1.750,0.593$ and $1.353 \%$ to $2.498,0.974$ and $1.484 \%$ respectively. It was also revealed from the figures 
that inoculation of potato plants with effective microorganisms significantly increased the percentage of nitrogen $(2.503 \%)$ and phosphorous $(0.919 \%)$ and insignificantly increased potassium $(1.480 \%)$ percentage in potato tuber as compared with untreated plants (1.923, 0.718 and $1.399 \%$ respectively).

Regarding the interactions between potassium fertilizer rates, biostimulants foliar spraying and effective microorganism's inoculation, the data presented in table (8) proved that all interactions significantly increased nitrogen and phosphorous in potato tuber. The highest percentages were obtained due to an addition of $40 \mathrm{~kg} \mathrm{~K}$ O/fed beside inoculation of potato plants with effective microorganisms then foliar spraying the potato shoots with seaweed extract. This treatment increased the percentage of nitrogen and potassium from 1.436 and $0.434 \%$ to 3.014 and $1.193 \%$ respectively. The data in the same table showed that potassium percentage in potato tuber insignificantly increased due to effective microorganism's inoculation and spraying plants with biostimulants in particular seaweed extract and an addition of the potassium fertilizer. The highest percentage $(1.800 \%)$ was obtained due to an addition of $80 \mathrm{~kg} \mathrm{~K} 2 \mathrm{O} / \mathrm{fed}$, inoculated with effective microorganisms and seaweed extract spraying as compared with untreated control plants (1.044\%).

\section{Economic considerations:}

Data in Table (9) indicated that addition of potassium fertilizer rates, inoculated potato plants with effective microorganisms and foliar application of biostimulants as well as their interactions increased the economic consideration relative to that of control.

Table (9): Comparative analysis of various treatments for their potential to give an optimum economic yield

\begin{tabular}{|c|c|c|c|c|c|c|c|c|}
\hline \multicolumn{3}{|c|}{ Treatment } & $\begin{array}{c}\text { Constant } \\
\text { cost }\end{array}$ & $\begin{array}{c}\text { Variable } \\
\text { cost }\end{array}$ & $\begin{array}{l}\text { Total } \\
\text { cost }\end{array}$ & $\begin{array}{c}\text { Total } \\
\text { income }\end{array}$ & Net income & Investment rate \\
\hline \multirow{6}{*}{ K20 } & \multirow{3}{*}{-EM } & W (1) & 163.17 & 0 & 163.17 & 176.25 & 13.08 & 0.080 \\
\hline & & SE (2) & 163.17 & 1.566 & 164.736 & 263.25 & 98.514 & 0.598 \\
\hline & & $\mathrm{HA} \mathrm{(3)}$ & 163.17 & 11.25 & 174.42 & 240 & 65.58 & 0.375 \\
\hline & \multirow{3}{*}{$+\mathrm{EM}$} & W (4) & 163.17 & 4.50 & 167.67 & 191.25 & 23.58 & 0.140 \\
\hline & & SE (5) & 163.17 & 6.066 & 169.236 & 270 & 100.764 & 0.595 \\
\hline & & $\mathrm{HA} \mathrm{(6)}$ & 163.17 & 15.75 & 178.92 & 266.25 & 87.33 & 0.488 \\
\hline \multirow{6}{*}{ K40 } & \multirow{3}{*}{-EM } & W (7) & 163.17 & 1.491 & 164.661 & 262.5 & 97.839 & 0.594 \\
\hline & & SE (8) & 163.17 & 3.057 & 166.227 & 416.25 & 250.023 & 1.504 \\
\hline & & $\mathrm{HA} \mathrm{(9)}$ & 163.17 & 12.741 & 175.911 & 367.5 & 191.589 & 1.089 \\
\hline & \multirow{3}{*}{$+\mathrm{EM}$} & W (10) & 163.17 & 5.991 & 169.161 & 288.75 & 119.589 & 0.706 \\
\hline & & SE (11) & 163.17 & 7.557 & 170.727 & 566.25 & 395.523 & 2.316 \\
\hline & & $\mathrm{HA}(12)$ & 163.17 & 17.241 & 180.411 & 393.75 & 213.339 & 1.182 \\
\hline \multirow{6}{*}{ K80 } & \multirow{3}{*}{-EM } & $\mathrm{W}(13)$ & 163.17 & 2.997 & 166.167 & 195 & 28.833 & 0.173 \\
\hline & & SE (14) & 163.17 & 4.563 & 167.733 & 262.5 & 94.767 & 0.564 \\
\hline & & HA (15) & 163.17 & 14.247 & 177.417 & 251.25 & 73.833 & 0.416 \\
\hline & \multirow{3}{*}{$+\mathrm{EM}$} & W (16) & 163.17 & 7.497 & 170.667 & 210 & 39.333 & 0.230 \\
\hline & & SE (17) & 163.17 & 9.062 & 172.232 & 311.25 & 139.018 & 0.807 \\
\hline & & $\mathrm{HA} \mathrm{(18)}$ & 163.17 & 18.747 & 181.917 & 292.5 & 110.583 & 0.607 \\
\hline
\end{tabular}

The data presented in the same Table clearly proved that addition of potassium fertilizer rate up to $80 \mathrm{~kg} \mathrm{~K} \mathrm{~K}_{2} \mathrm{O} / \mathrm{fed}$ increased all economic characters represented as total cost, total income, net income and investment 
Arafa A. A. et al.

rate. Addition of $40 \mathrm{~kg} \mathrm{~K} \mathrm{~K}_{2} \mathrm{O} / \mathrm{fed}$ gave the highest values $174.661,262.5$, 97.839 and 0.594 LE relative to control or high potassium fertilizer rate. Inoculated potato plants with effective microorganisms increased total income, net income and investment rate from 176.25, 13.08 and 0.080 to 191.25, 23.58 and 0.140 LE.

Regarding the effect of both biostimulants, the data in Table (9) proved that application of either seaweed extract or humic acid increased the total income, net income and investment rate as compared to untreated plants. Seaweed extract was more effective than humic acid which increased total income, net income and investment rate from 176.25, 13.08 and 0.080 to $263.25,98.514$ and 0.598 LE. Regarding the interactions effect, the data presented in Table (9) indicated that all interactions having a positive effect on increasing all economic consideration. The data indicated that foliar application of seaweed extract with or without addition of effective microorganisms under all potassium fertilizer rates gave the higher values than humic acid application under the same conditions. The highest values were obtained due to foliar application of seaweed extract with effecticve microorganisms and addition of $40 \mathrm{~kg} \mathrm{~K} 2 \mathrm{O} / \mathrm{fed}$; this treatment gave the highest total income (566.25 LE compared with control 176.25 LE) and net income (395.525 comparing with control 13.08LE) as well as high rate of investment (2.316) as compared with control (0.080).

\section{DISCUSSION}

Tuber yield:

An increase in potato yield as indicated in the present investigation due to applying potassium was reported by Radwan et al. (2011) who indicated that potassium fertilization in potato resulted in significant increase in tuber yield. The role of $\mathrm{K}$ in increasing the yield and its components might be attributed to its function in plants which includes energy metabolism and enzyme activation on exchange rate and nitrogen activity as well as enhanced carbohydrates movement from shoot to storage organs (Marschner 1997). Moreover, potassium application enhanced the stomatal resistance coupled with reduced transpiration rate and increased relative water content, thus, may improve water storage capacity of the cells and providing favorable conditions for better yields (Umar and Bansal 1995).

Concerning the effect of effective microorganisms, Lin (1991) indicated that soils that are treated with EM became more friable, less compact and better drained. These providing a more favorable environment for crop growth and tuber production. Similarly, In a field experiment Sherchand (2000) observed $15-20 \%$ and $3-12 \%$ increase in rice and wheat yield by EM applications. The enhancing effect of EM on yield and its component may be attributed to one or more of the following factors: improving root growth and functions and enhancing mineral uptake in the plant (Stancheva et al. 1995), producing the phytohormones indole acetic acid, gibberellins and cytokinin, also reduce of abscic acid, these phytohormones, particulary IAA, play an essential role in plant growth stimulation (Kawthar et al. 2002) and producing amino acids as well as 
phenolic compounds (El-Morsi et al. 2000). The increase of tuber numbers and tuber dry weight $(\mathrm{g})$ per plant may be due to the EM application stimulated plant roots, absorption of nutrients and photosynthesis process which led to produce vigorous plants, numerous tubers, bigger tuber size and total tuber yield (Hammad and Abdel-Ati 1998).

The influence of humic acid on plant growth and yield, have been investigated on biometric factors and numerous studies have shown that humic substances enhance plant growth, increased grain yield and its quality in various cereal crops (Radwan et al. 2011). The positive responses of yield of potato to application of humic acid have reported earlier (Zhang and Ervin 2004). The favorable effect of foliar spraying of humic acid on the crop yield was attributed to the increased content of chlorophyll in the leaves and enhanced photosynthetic activity and higher uptake of nutrients like $P$ (Senthilkumar 1995). The mechanism of humic acid which stimulate plant growth, yield and quality is not fully clear, although there are some theories which probably work together. a) Application of HA stimulate root growth, increase proliferation of root hairs, production of smaller but more ramified secondary roots and enhancement of root initiation (Canellas et al. 2002). b) The positive effect of humic on plant growth and productivity, which seem to be mainly due to hormone-like activities of the humic acids through their involvement in cell respiration, photosynthesis, oxidative phosphorylation, protein synthesis and various enzymatic reactions (Muscolo et al. 1999).

The enhanced effect obtained by seaweed extract may be brought about by more assimilates going to the tubers and/or more enhancement in sink strength of the tubers to attract more water and assimilates due to higher concentrations of promoting substances. Similar results with application of seaweed extract are reported (Ezzat et al. 2011, Zodape et al. 2011). Increase in yield and yield attributes may be due to the presence of plant growth regulators in the extract. In this concern, seaweed (Ascophyllum nodosum (L.) Le Jolis] extract has been shown to contain biologically active concentrations of natural cytokinins such as trans-zeatin riboside (t-ZR) and isopentenyl-adenine (Zhang and Ervin 2004).

Tuber quality:

Results of the present experiment and others indicated that potassium nutrition influences tuber size, specific gravity, reducing sugar content and storage quality (Karam et al. 2009, and Rai et al. 2010). With a shortage of potassium many metabolic processes are affected, like the rate of photosynthesis, thereafter of translocation and enzyme systems (Marschner 1997). Moreover, potassium enhanced quality as it facilitates the uptake and assimilation of nitrogen into simple amino acids and amide which favor peptide synthesis leading to protein synthesis. Potassium improves the transfer of radiation energy into primary chemical energy in the form of ATP (Photophosphorylation) and NADPH. This energy is required for all synthetic process in plant metabolism, resulting in production of carbohydrates, proteins, and lipids, which express the quality of the crops. The high energy status in crops well supplied with potassium also promotes synthesis of secondary metabolities, like vitamin C (Mengel 1997). Potassium plays an important role in the transport of assimilates and nutrients (mainly sucrose) to 
Arafa A. A. et al.

the tuber (Mengel 1997). It is generally agreed that starch content is enhanced by potassium application, so long as this is to correct potassium under-nutrition, whilst heavy doses of potassium may decrease starch content (Martin-Prevel 1989). In order to receive chips with a desirable light color, soluble sugars content of potato should not exceed $0.25 \%$ (Perrenoud 1993). Accumulation of soluble sugars and decrease of starch in potato tubers are the cause of undesired dark-colored potato chips which occur under low potassium nutrition level (Perrenoud 1993). Concerning the ion percentage in potato tuber, there are many reports agree with the observations in the present study which indicated that addition of potassium fertilizer increased the percentage of ions in the tuber (Karam et al. 2009). As regard to protein, carbohydrate and ascorbic in potato tuber, there are many reports indicate that, in most cases, application of potassium fertilizers increased tuber quality represented as protein, carbohydrates and ascorbic acid. This observation was agreement with some authors i.e. Ahmed et al. (2009) and Rai et al. (2010). The specific gravity is a measure of quality in potato tuber which is related to the dry matter contents in the tubers. The specific gravity was more in potato tubers harvested from potassium treated plants (Malik 1995). Potatoes with high specific gravity are preferred for preparation of chips and French fries.

The obtained results related to the positive effect of EM inoculation on tuber quality are in agreement with those found by Mohamed, Faten (2007) who reported that application of EM increased significantly TSS\%, TSS/acid ratio but decreased acidity\% and total carbohydrates content. Ascorbic acid (AsA) plays important roles in the human organism, such as conjunctive tissue formation, ion transportation, and cell protection against free radicals. The beneficial effects of EM on increasing tuber protein may be attributed to their effects on reducing nitrate concentration in the tubers. This reduction may be inducing the accumulation and utilization of nitrate in plant to produce proteins (Hanafy Ahmed et al. 2002). It is important here to mention that the beneficial effects of EM inoculation with appropriate strains might be attributed to increase; 1 ) the symbiotic $\mathrm{N}$ fixation in the soil, 2) levels of free amino acids in the cell-sap, development and physiological enzymatic activity and growth rate of roots (Ghallab and Salem 2001). Inoculation with EM enhanced the plant growth and nutrients uptake (El-Shahawy 2003). The increase of phosphorus content in potato tubers due to the interaction between bio-fertilizers may be attributed to their effects on the availability of soil phosphorus which caused an increase in absorbing various nutrients (ElAgroudi et al. 2003). The increase in tubers potassium content under EM reflects an enhanced growth which might be possibly due to the role of microorganisms in supplying great amounts of both water-soluble and amorphous potassium which was reflected in plant uptake (Afify and Bayoumy 2001). It could be concluded that, the increasing values of nitrogen, phosphorus and potassium as a result of inoculation with EM used under different doses of NPK may be due to the favorable effect of EM on the absorbing various corresponding nutrients during the two growing seasons.

The favorable influences of seaweed extract on chemical characteristics of potato tuber may be ascribed to its simulative effect on 
photosynthesis process and its concentration of some promoter hormones such as cytokinin which is closely involved in cell division, protein, carbohydrates and chlorophylls formation (Featonby-Smith and Van Standen 1984). The increase in the protein content might be due to absorption of most the necessary elements by the seedlings (Sivasankari et al. 2006). Recently, Ezzat et al. (2011) on potato found that foliar application of seaweed extract with $50 \%$ NPK fertilizer significantly increased yield characters i.e. specific gravity and starch and reduced reducing sugars. Zodape et al., (2011) found that, foliar application of seaweed extract led to an increase in tomato yield and yield contributing characters in almost all concentrations, as well as fruit quality. Enhancement in vitamin $\mathrm{C}$ of Trigonella foenum-graecum (Khemnar and Chaugule (2000), increase in $\mathrm{N}$ of beans (Beckett et al. 1994) and carbohydrates, protein, vitamin $\mathrm{C}$ and ions in tomato plant (Zodape et al. 2011) has been reported for plants treated with seaweed extract.

\section{REFERENCES}

Abdel-Aal R.M. (1971): Effect of groundwater and parent material on different soil characteristics in the North Nile Delta. Ph.D. Thesis, Fac. of Agric., Cairo Univ., Egypt.

Afify, Aida H. and Samia M.M. Bayoumy (2001): Effect of certain silicate bacteria on primary silicate minerals. Egypt J. Agric Sci., Mansoura Univ., 26(5): 3111-3125.

Ahmed A.A., M.M.H.A. El-Baky, F.S.A. El-Aal, and M.F. Zaki (2009): Comparative studies of application both mineral and bio-potassium fertilizers on the growth, yield and quality of potato plant. Research Journal of Agriculture and Biological Sciences. 5(6):1061-1069.

AOAC (1990). In: Helrich K. (ed.), Official methods of analyses of the association of official analytical chemists, Washington, DC.

Beckett R.P., A.D.M. Mathegka and J. vanStaden (1994): Effect of seaweed concentrate on yield of nutrient stressed tepary bean (Phaseolus acutifolius Gray). J. Appl. Phycol. 16:429-430.

Cakmak, I., C. Hengeler, and H. Marschner (1994): Partitioning of shoot and root dry matter and carbohydrates in bean plants suffering from phosphorus, potassium and magnesium deficiency. J. Exp. Bot. 45:1245-1250.

Canellas L.P., F.L. Olivares, A.I. Okorokovha and A.R. Facanha (2002): Humic acids isolated from earthworm compost enhance root elongation, lateral root emergence and plasma membrane $\mathrm{H}^{+}$-ATPase activity in maize root. Plant Physiol., 130:1951-1957.

Cooper T.G. (1977). The tools of biochemistry.A Wiley-Interscience Pub. John Wiley and Sons, New York.

Crouch I.J and J. Van Staden (1993): Effect of seaweed concentrate from Ecklonia maxima (Osbeck) Papenfus on Melodogyne incognita infestation on tomato. J. Appl. Phycol. 5:37-43.

El-Agroudi M.W., H.A. El-Fadaly, H.A. Shams El-Din and A.M. El-Shehawy (2003): Effect of phosphorus fertilization and grains inoculation with phosphate dissolving bacteria on microbiology of rhizosphere, wheat yield and yield components.Egypt J.Agric. Sci., Mansoura Univ., 28(8): 6353-6369. 
Arafa A. A. et al.

El-Morsi E.A., G.F.Abdel-Naem, E.S. Shaker and M.A.Ghazy (2000): Influence of bio-fertilization on total phenolic compounds and antioxidative activity potato tubers (Solanum tuberosum, L.). Arab Universities J. of Agric. Sci., 8(1):1-18.

El-Shahawy A.M.B. (2003): Effect of phosphate dissolving bacteria on yield and nutrient uptake of faba bean and wheat plants. Ph. D. Thesis, Fac. of Agric., Mansoura Univ., Egypt.

Ezzat A.S., H.EL-S. Asfour and M.H. Tolba (2011): Improving yield and quality of some new potato varities in winter plantation using organic stimulators. J. Plant Production, Mansoura Univ., 2(5): 653-671.

Featonby-Smith B.C and J . Van Staden (1984): The effect of seaweed concentrate and fertilizer on growth and the endogenous cytokinin content of Phaseolus vulgaris. South African J. Bot. 3 (6):375-379.

Fike J.H., V.G. Allen, R.E. Schmidt, X. Zhang, J.P. Fontenot, C.P. Bagley, R.L. Ivy, R.R. Evans, R.W. Coelho and D.B. Wester (2001): TascoForage: I. Influence of a seaweed extract on antioxidant activity in tall fescue and in ruminants. J Anim Sci 79:1011-1021.

Gedroits K.K. (1963): Chemical analysis of soils. Ed. National Sci Foundation, Washington Dc. By The Isreal program for scientific translation, Jerusalem.

Ghallab A.M. and S.M. Salem (2001): Effect of some bio-fertilizer treatments on growth, chemical composition and productivity of wheat plants grown under different levels of NPK fertilization. Egypt Annals Agric Sci., Ain Shams Univ., Cairo, 46(2):485-509.

Hammad A.M.M. and Y.Y.Abdel-Ati (1998): Reducing of nitrate and nitrite contents of potato tubers via Bio-fertilization with Azospirillum and VAMycrrohyzal Fungi. Egypt J. Agic. Sci., Mansoura Univ., 23(6):25972601.

Hanafy Ahmed A.H., M.R.A. Nesiem, A.M. Hewedy and H.E.E. Salam (2002): Effect of organic manure, bio-fertilizers and NPK mineral fertilizers on growth, yield, chemical composition and nitrate accumulation of sweet pepper plants. Proceeding of the 2th Congress Recent Technologies in Agric. Fac. of Agric., Cairo Univ., Egypt 28-30 October, pp.932-955.

Karam F., Y. Rouphael, R. Lahoud, J. Breidi, and G. Colla (2009): Influence of genotypes and potassium application rates on yield and potassium use efficiency of potato. Journal of Agronomy. 8 (1): 27-32.

Kawthar A.E.R., S.M. Selim, S.A. Nasr (2002): Nitrate and nitrite accumulation in potato tubers in relation to mineral nitrogen and biofertilization. Egypt Annals of Agricultural Science (Cairo), 47(1):107122.

Khemnar A.S. and B.B. Chaugule (2000): Enhanced vitamin C level in Trigonella foenum-graecum $\mathrm{L}$. treated with liquid seaweed extract. IN Nat. symp Seaweed of India: Biodiversity and Biotechnology, (Central Salt and Maine chemicals Research Institute, Bhavnagar), 12-14 sept., 2000.

Lin DL (1991): Nature farming in Taiwan: Effect of EM on growth and yield of paddy rice. p. 125-131. In J.F. Parr, S.B. Hornick, and C.E. Whitman (ed.) Proceedings of the First International Conference on Kyusei Nature Farming. U.S. Department of Agriculture, Washington, D.C., USA.

Malik C.P. and A.K. Srivastava (1979): Text book of plant physiology. New Delhi, India: Kalyani Publishers. 
Malik N.J. (1995): Potatoes in Pakistan: A Hand Book. Pak Swiss Potato Development Project, Pakistan Agricultural Research Council, Islamabad. ISBN 969-8301-00-3.

Marschner H. (1997): Mineral nutrition of higher plants. 2nd ed. Acad. Press Inc., London.

Martin-prevel P.J. (1989): physiological processes related to handling and storage quality of crops . Im : proceedings of the 21st IPI colloquium on : methods of $\mathrm{k}$ Research in plants, held at lou vain - la - nerve , Belgium , 19 - 21 June 1989. International potash - Institute , Bern , Switzerland .PP.219-248.

Mengel K. (1997): Impact of potassium on crop yield and quality with regard to economical and ecological aspects. In: Proceeding of IPI Regional Workshop on: Food Security in the WANA Region, The Essential Need for Balanced Fertilization, held at Bornova, Lamir Turkey, and International Potash institute Bern, Switzerland, pp.157-174.

Mohamed Faten F.E. (2007): The effect of growth regulators and partial replacement of mineral fertilizers by bio-fertilizers on botanical characters of caraway (Carum carvi L.) and anise (Pimpinella anisum L.) plants. Ph.D. Thesis, Fac. Agric.Fayoum Univ., Egypt.

Muscolo A., F. Bavolo, F. Gionfriddo and S. Nardi (1999): Earthworm humic matter produced auxin-like effects on Daucus carota cell growth and nitrate metabolism. Soil Biol. Biochem. 31: 1303-1311.

Norman G.R. and D.L. Streiner (2003): PDQ Statistics, 3rd Ed. BC Deckker Inc, London. ISBN 1-55009-2073.

Pascual J.A., C. Garcia and T. Hernandez (1999): Comparison of fresh and composted organic waste in their efficacy for the improvement of arid soil quality. Bioresources Technol., 68: 255-64.

Perrenoud S. (1993): Fertilizing for high yield potato. IPI Bulletin 8. 2nd Edition, International Potash Institute, Basel, Switzerland.

Peterburgski A.V. (1968): Hand book of agronomy chemistry. Kolos Publishing House Moscow, P. 29-86.

Pondey S.N. and A. Chadha, (1996): Economic Botany, New Dalhi, press p. 57-58.

Radwan E.A., Z.S.A. El-Shall and R.A.M. Ali (2011): Effect of potassium fertilization and humic acid application on plant growth and productivity of potato plants under clay soil. J. Plant Production, Mansoura University 2(7):877-890.

Rai G.K., P.K. Rai, S.K. Singh, A.P. Rai and A.K. Khokhar (2010): Effect of potassium on yield and quality of potato (Solanum tuberosum L.) tubers. Environment and Ecology. 28(1B):694-696.

Sadasivam S. and A. Manickam (1996): Biochemical methods, Second eddition, New age international. India.

Sangakkara U.R. and T. Higa (2000): Kyusei Nature Farming and EM for enhanced smallholder production in organic systems. In Proceedings of the 13th International Scientific Conference of IFOAM. Alfoeldi, T et al (Ed). FiBL, Basel, Switzerland: 268.

Senthilkumar K. (1995): Studies on the effect of I igni te der ived humic substances and nitrogen on low land rice. M.Sc. (Ag.) Thesis submitted to and approved by Annimalai University, Tamil Nadu.

Sherchand K. (2000): Reponse of effective microorganisms (EM) and other nutrients to rice and wheat under field conditions in Khumaltar, Nepal. EM World J 1:40-44. 
Arafa A. A. et al.

Sivasankari S., M. Chandrasekaran, K. Kannathasan and V. Venkatesalu (2006):Studies on the biochemical constituents of Vigan radiate Linn. treated with seaweed liquid fertilizer, Seaweed Res.Utiln.28(1):151158.

Slinkard K. And V.L. Singleton (1977): Total phenol analyses: automation and comparison with manual methods. Am. J. Enol. Viticult. 28:49-55.

Stancheva I., I. Dimitrov, N. Kaloyanova, N. Dinev and N. Poushkarov (1995): Improvement of the nitrogen uptake and nitrogen content in maize (Zea mays) by inoculation with Azospirillum brasilense. Agrochimica, 39: 299-306.

Umar S. and S.K. Bansal (1995): Potassium requirement of mustard (Brassica juncea L.) under moisture stress conditions. Plant Physiol \& Biochem, New Delhi, 22(2):130-135.

Zhang X. and E.H. Ervin (2004): Cytokinin-containing seaweed and humic acid extracts associated with creeping bentgrass leaf cytokinins and drought resistance. Crop Sci 44:1-10.

Zhang X. and E.H. Ervin (2008): Impact of seaweed extract-based cytokinins and zeatin riboside on creeping bentgrass heat tolerance. Crop Sci 48:364-370.

Zodape S.T., Abha Gupta, S.C. Bhandari, U.S. Rawat, D.R. Chaudhary, K. Eswaran and A. Chikara (2011): Foliar application of seaweed sap as biostimulant for enhancement of yield and quality of tomato (Lycopersicon esculentum Mill.). J. of Scientific and Industrial Research, 70: 215-219.

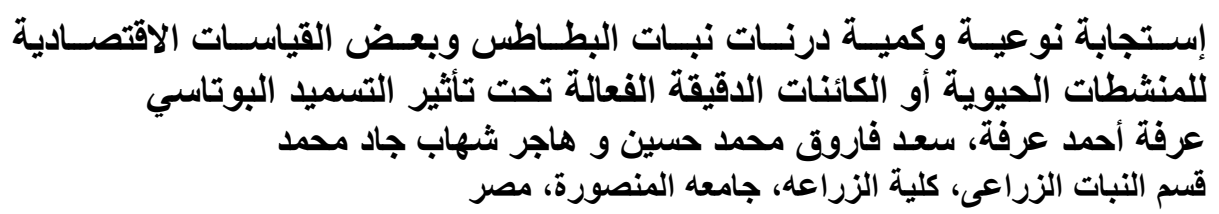

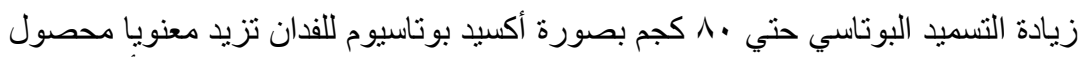

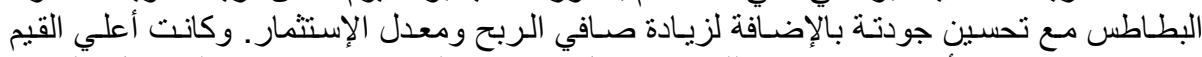

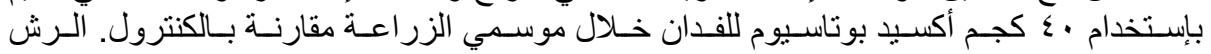

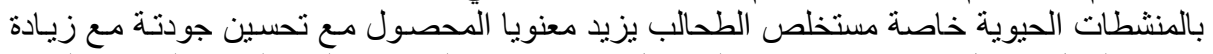

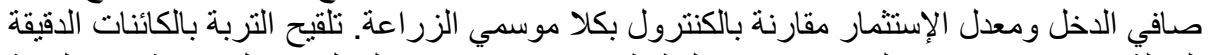

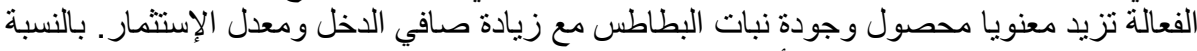

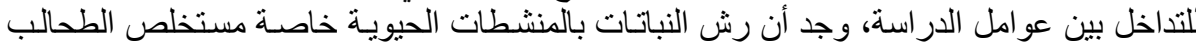

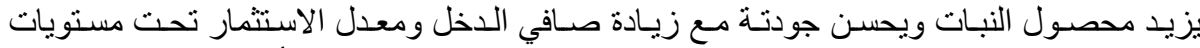

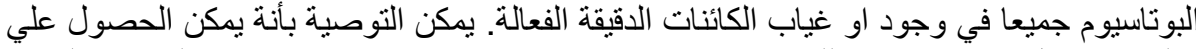

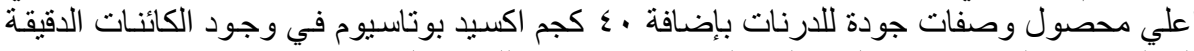
الفعالة ورش النباتات بمستخلص الطحالب بتركيز . ـ ملإيجر ام/لتر .

كلية الزراعة - جامعة المنصورة

كلية الزراعة - جامعة القاهرة

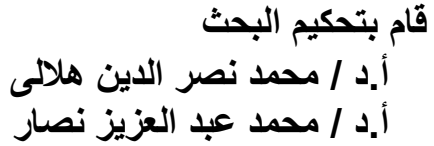


RESPONSE OF TUBER YIELD QUANTITY AND QUALITY OF POTATO PLANTS AND ITS ECONOMIC CONSIDERATION TO CERTAIN BIOREGULATORS OR EFFECTIVE MICROORGANISMS UNDER POTASSIUM FERTILIZATION

Arafa, A. A. ; S. F. M. Hussien and Hager S. G. Mohamed

Agric. Bot. Dept., Faculty of Agric. Mansoura University

\begin{abstract}
Increasing potassium fertilizer rate up to $80 \mathrm{~kg} \mathrm{~K}{ }_{2} \mathrm{O} / \mathrm{fed}$ significantly increased yield and improved its quality as well as increased the net income and investment rate. The highest values were obtained due to application of $40 \mathrm{~kg} \mathrm{~K}_{2} \mathrm{O} / \mathrm{fed}$ in the first and second seasons as compared with untreated plants. Exogenous application of biostimulants, in particular, seaweed extract significantly increased yield and improved its quality as well as increased the net income and investment rate as compared to control in both seasons. Addition of effective microorganisms to the soil significantly increased yield and improved its quality as well as increased the net income and investment rate.

As for the interactions, application of biostimulants, in particular, seaweed extract, significantly increased yield and improved its quality as well as increased the net income and investment rate under all potassium fertilizer rates with or without an addition of effective microorganisms. The highest value was obtained under the treatment of $40 \mathrm{~kg} \mathrm{~K}$ O/fed with an addition of effective microorganisms and spraying plants with $500 \mathrm{mg} / \mathrm{l} \mathrm{seaweed} \mathrm{extract} \mathrm{as} \mathrm{compared} \mathrm{to} \mathrm{control} \mathrm{plant} \mathrm{during} \mathrm{the}$ first and second growing seasons.
\end{abstract}




\section{Arafa A. A. et al.}

